\title{
Radiologic Anatomy of the Abdominal Aorta and their Large Branches
}

\author{
By
Christian Leithner, Helmut Sinzinger, Johann Hohenecker, Lothar Wicke, Fritz Olbert and Walter Feigl*

\begin{abstract}
$2^{\text {nd }}$ Dept. of Internal Medicine (Head: Prof. DDDr. K. Fellinger), $1^{\text {st }}$ Dept. of Anatomy (Head: Prof. Dr. H. Ferner), Dept. of Radiation Therapy (Head : Prof. Dr. K. H. Kärcher), Faculty of Medicine, University of Vienna, Angiologic-Diagnostic Institute (Dr. F. Olbert) of the 1st Dept. of Surgery, Hospital of Vienna-City-Lainz (Head: Doz. Dr. H. Denck) and Dept. of Pathology (Head: Prof. Dr. J. H. Holzner), Faculty of Medicine, University of Vienna, Austria.
\end{abstract}

-Received for Publication, February 10, 1975-

\section{Introduction}

The exact knowledge of the normal and radiologic anatomy of blood vessels is absolutely necessary for the diagnostics of malformations and acquired degenerative variations. The date of length, calibre and angle of the divisions of arteries became of increasing importance in the last years. Particularly essential are these data in the age of growth. Taber et al. (1972) were able to derive a linear correlation of the data to the body surface in children. If we know the normal parameters we can conclude as to functional impairments caused by irradiation (Colquhoun 1966), atherosclerosis (Steinberg et al. 1965) and other alterations. The correlation of data of morphological and angiographic investigations became of increasing importance.

\section{Material and Methods}

We used full size angiograms of the abdominal aorta done with a retrograde catheter after the puncture of the femoral artery. The distance of the focus to the film was $1.2 \mathrm{~m}$. The coefficient of enlargement of the radiographic image in relation to the object was 1.33. Hence, all linear measurements of anatomic details on films were in

* We thank Doz. DDr. Mag. L. Reisinger (Institute for Statistics, Univ. Vienna) for his valuable help in the statistical operations. 
reality one-third smaller. We investigated the angiograms of 61 grown-ups, 33 males and 28 females, aged between 17 and 74 years. We did not evaluate material suspect of anatomic varieties. The level of origin of an artery was regarded in projection to the sceletal system. The breadth of the column of contrast medium was taken as the calibre of the vessel (see Fig. 1). The length of the vessel was measured with a length measurer. We used the following statistical operations : mean values, standard deviations, t-test and F-test.

\section{Results}

The calibre of the abdominal aorta (see Figs. 2 and 3) decreased statistically significant in both sexes from $\mathrm{Th}_{12}$ (mean value $26 \mathrm{~mm}$ ) down to the aortic bifurcation (mean value $19 \mathrm{~mm}$ ). There were statistically significant sex-differences (see Fig. 3). The means calibre of the aorta was $2 \mathrm{~mm}$ minor in the female than in the male sex. In its course the aorta approached the median line more and more (see Fig. 2). This was always highly significant regarding the whole course. In some cases there were considerable oscillations of the calibre (see Fig. 4) caused by atherosclerosis or there was a marked tortuosity of the aorta and the iliac arteries resulting in a repeated crossing of the aorta over the median line (see Fig. 5). The mean angle of the aortic bifurcation was $37^{\circ}$ (see Fig. 6). The mean angle of the iliac bifurcation was $29^{\circ}$ on the right and about $20^{\circ}$ on the left side. In the mean the aortic bifurcation had a level of $\mathrm{L}_{4}$ (see Fig. 7). We observed a decrease of the bifurcation with advancing age. The sex distribution showed a similar result in females and males (see Fig. 8).

The mean calibre of the left and right renal artery was practically identical and measured about $7.8 \mathrm{~mm}$ (see Fig. 8). In the female sex the calibre was about $0.8 \mathrm{~mm}$ minor than in the male. The mean calibre of the splenic artery differed statistically significant to the calibre of the renal arteries. The renal arteries originated at a level of $\mathrm{L}_{1}-\mathrm{L}_{2}$ (see Fig. 10). In our material the level of origin was slightly higher on the right than on the left side. We found, that the level of origin of the renal arteries decreased significantly with advancing age. In men (see Fig. 11) the level was in the mean about $1 / 2$ vertebral body lower in older than in younger individuals. The same result (see Fig. 12) was found in women.

The splenic artery originated in women and men at a level of $\mathrm{Th}_{12}-\mathrm{L}_{1}$ (see Fig. 13). The level decreased with advancing age, but this was not significant in our material. In this artery the increase of length with age was particularly marked. Sometimes the total length reached a value up to the four fold of the direct distance from 
the origin to the hilus (see Fig. 14).

The calibre of the right common iliac artery did not differ significantly to the left (see Fig. 15). In the external iliac arteries we found a similar result. The mean calibre of the internal iliac artery was $6.1 \mathrm{~mm}$ on the right and $6.5 \mathrm{~mm}$ on the left side, but this difference was not statistically significant. The length of the common iliac arteries down to the iliac bifurcation varied considerably. This was due to the variable and age-dependent level of the bifurcations and to the tortuous course of the vessels. In the mean the tortuous course was somewhat more distinct on the left than on the right side. Nearly always such tortuosity occurred in hypertensive partients (see Figs. $16,1,5)$.

\section{Discussion}

The renal arteries are of particular clinical importance. Abnormal calibres, wall alterations and length differences in the angiogram may be the only symptom of an incipient impairment of function. The calibre is essential for diagnoses, because of reduction or irregularity of it can indicate renal or renovascular diseases, such as vessel hypoplasia, fibromusclar dysplasia and so on. In our material the level of the origin was slightly higher on the right than on the left side. This confirms the results of Hafferl (1957), Töndury (1970), Luzsa (1972) and Wicke et al. (1974). Heidsieck (1928) related the level of origin of the renal arteries to the origin of the superior mesenteric artery. He found the origin of the renal artery in the mean $0.1 \mathrm{~cm}$ higher on the right than on the left side. Contrary to the results of the former investigators, Vogler and Herbst (1958) wrote, that the origin of the renal arteries was in the mean higher on the left than on the right side. The level of origin of the renal arteries in relation to the vertebral column was investigated by several authors. Luzsa (1972) found the level in more than $50 \%$ of the cases within the lower half of $\mathrm{L}_{1}$ and in $25 \%$ of cases at the first lumbar intervertebral disc. The renal arteries originated only in a small part of the cases at $\mathrm{L}_{2}$. De Luca and De Serio (1960) and Olsson (1964) achieved similar results. In the investigations of Danek (1973/4) the origin had a level of $\mathrm{L}_{1,8}$ (lowest third), $\mathrm{L}_{1,4}$ (intervertebral disc) or $\mathrm{L}_{2,1}$ in $57 \%$ of the cases it was on the right and in $71 \%$ on the left side. Wicke et al. (1974) wrote, that the level ranged within $\mathrm{Th}_{12 ; 3}-\mathrm{L}_{2,3}$. Accessory renal arteries were not evaluated. In over $70 \%$ of the cases examined by Edsmann (1957) the level of the origin was found at the first lumbar vertebral body and intervertebral disc. The level ranged within $\mathrm{L}_{1 / 2}, \mathrm{~L}_{1 / 3}, \mathrm{~L}_{1 / 4}$ or $\mathrm{L}_{2,1}$ in more than $80 \%$ of the cases investigated by Ney and Friedenberg 
(1968). Often it is very hard to notice the real origin of the renal arteries, because the shadow of the aorta may cover if. Therefore the origin is often evaluated at a lower level in the angiogram than in the sections revealing the actual origin. Pietrowski and Krylow (1968) investigated the distance between the origins of the coeliac trunk and the renal arteries and found generally two types of behaviour. The "compact type" showed a short distance, the "disperse type" of branching a long one. There are different results concerning the calibre of the renal arteries in the respective literature. The mean calibre of the renal arteries was $5.5 \mathrm{~mm}$ in Merklin and Michels (1957), $6.1 \mathrm{~mm}$ in Baudisch and Arndt (1969), who measured $2 \mathrm{~cm}$ from the origin, and $5 \mathrm{~mm}$ in Pietrowsky and Krylow (1968). Edsmann (1957) found a mean calibre of $7.9 \mathrm{~mm}$ in the male and $6.4 \mathrm{~mm}$ in the female sex, Danek $8 \mathrm{~mm}$ in the male (ranging from 6 up to $8 \mathrm{~mm}$ ) and $7.2 \mathrm{~mm}$ (ranging from 5 up to $9 \mathrm{~mm}$ ) in the fomale sex. Danek measured the calibre of the renal artery $5 \mathrm{~mm}$ from the origin. He also evaluated accessoric vessels, which was left out, because then it would have been hard to get statistically significant calibre values. In the investigations of Piasecki (1962) the calibre of the renal artery ranged from 2 up to $9 \mathrm{~mm}$, in Hou Jensen (1947) from 4 up to $7 \mathrm{~mm}$ and in Bochenek rnd Reicher (1958) from 6 up to $8 \mathrm{~mm}$. Adachi (1928), Bochenek and Reicher (1958) and Hou Jensen (1947) found a greater length of the renal artery on the right side than on the left one. This was caused by the aorta which was running somewhat on the left side. According to the results of Odman (1958) the calibre of the splenic artery ranged from 4 up to $8 \mathrm{~mm}$ with a mean value of $5.5 \mathrm{~mm}$. The results of our investigations about the course and calibre of the abdominal aorta were similar to those of Steinberg (1965), who wrote that the aorta of the grown-up approached the median line and became came smaller in its course. Luzsa (1972) found the upper third of the abdominal aorta in the median line or a little more to the left, then a straight or little bent course followed. In the material of Bochenek and Reicher (1958) the mean calibre of the aorta was $20 \mathrm{~mm}$ at the beginning of the abdominal part and $17 \mathrm{~mm}$ at the bifurcation. Steinberg et al. (1965) found a signifiant sex-difference of $2 \mathrm{~mm}$. In our material the difference was just as statistically significant. The level of the aortic bifurcation is usually reported in literature at $\mathrm{L}_{4}$ (Luzsa 1972, De Luca and De Serio 1960). The mean angle of the aortic bifurcation was $37^{\circ}$ in our material. A much higher value was found by Luzsa in 1972 when he examined sections: $65^{\circ}$ in the male and $75^{\circ}$ in the female sex. Lize (1968) stated that the angle of the aortic bifurcation increased with age. We did not find such behaviour in our material. De Luca and De Serio (1960) reported that the length of the common iliac artery was $6.5 \mathrm{~cm}$ on the right and $6.3 \mathrm{~cm}$ on the 
left side. The calibre was $0.89 \mathrm{~cm}$ on the right and $0.83 \mathrm{~cm}$ on the left side. Reich et al. (1964) found in $72 \%$ a longer common iliac artery on the left than on the right side. These authors described a lower iliac bifurcation on the left than on the right side. Luzsa (1972) evaluated the variable form of the internal iliac artery. The course was lateral concave in $39 \%$; straight in $31 \%$, medial concave in $22 \%$ and tortuous in $8 \%$. The investigations of De Luca and De Serio revealed, that the mean length of the internal iliac artery was $3.9 \mathrm{~cm}$ on the right and $4.0 \mathrm{~cm}$ on the left side, the external iliac artery was $9.0 \mathrm{~cm}$ on the right and $8.8 \mathrm{~cm}$ on the left side. The calibre of the external iliac arteay ranging from 0.4 up to $1 \mathrm{~cm}$, in the mean $0.68 \mathrm{~cm}$. Muratori (1963) saw a continual increase of the calibre of the abdominal aorta and its great branches with increasing are. Taber et al. (1972) derived a linear relation between data of vessels (the calibre of the aorta at $\mathrm{Th}_{11}$, at the origin of the renal arteries and at the bifurcation and the calibre of the common iliac arteries) and body surface.

In our material the origins of the great vessels and the bifurcations were found at a lower level with increasing age. This resulted in a jolting of the iliac arteries. Together with the increase in length it caused the tortuous course of these vessels. This was particularly marked in hypertensive patients and might be one of the factors causing disturbances of the peripheral circulation. In the evaluation of angiograms made by percutaneous (first by Dos Santos et al. 1931) or retrograde aortography we have to take into consideration the limitation of the method. We are able to measure only the course and breadth of a column of contrast medium. The third dimension of the vessel course be evaluated by angiographic investigations in at least two planes. Up to this time such investigations have been carried out in cerebral vessels, but not yet in abdominal arteries. Our results can be related to those of Lize (1968), who made analogous investigations on the corpse. There have been combined investigations to compare the results, so by Goldberg (1965). The differences of angiographic results to those found in sections may amount to more than 50\%. Tassel (1972) used catheters with known and normed size to decrease the failures made in the evaluations of angiograms.

\section{Summary}

We investigated the angiograms of 61 grown-up, 33 males and 28 females, aged between 17 and 74 years. In its course the aorta was gradually approaching the median line, the calibre decreased from $\mathrm{Th}_{12}(26 \mathrm{~mm})$ down to the aortic bifurcation $(19 \mathrm{~mm})$. The aortic bifurcation had a mean angle of $37^{\circ} \mathrm{C}$, the iliac bifurcation one of $29^{\circ}$ on 
the right and $20^{\circ}$ on the left side. In the mean the aortic bifurcation had a level of $L_{4}$. The mean calibre of the left and right renal artery measured about $7.8 \mathrm{~mm}$ and differed significantly from the calibre of the splenic artery. In the mean the level of the origin of the renal arteries was slightly higher on the right than on the left side. The side-differences of the calibres of the common external and internal iliac arteries were not significant. In the higher age groups we observed a lowering of the aortic bifurcation and the origin of the renal arteries. The increase in length was particularly marked in the splenic artery. The length of the common iliac arteries varied considerably. This artery was rather more tortuous on the left than on the right side. This tortuosity was nearly always found in patients suffering from hypertension.

\section{Zusammenfassung}

Wir untersuchten die Angiogramme von 61 Personen, 33 Männern und 28 Frauen, im Alter zwischen 17 und 74 Jahren. Die Aorta näherte sich in ihrem Verlauf der Medianen mehr und mehr. Ihr Kaliber nahm von $\mathrm{Th}_{12}(26 \mathrm{~mm})$ bie zur Aortenbifurkation (19 mm) laufend ab. Die Aortenbifurkation wies einen Durchschnittswinkel von $37^{\circ}$ auf, die Werte der Iliakabifurkation betrugen $29^{\circ}$ rechts und $20^{\circ}$ links. L, war die Durchschnittshöhe der Aortenbifurkation. Das Durchschnittskaliber der Nierenarterie betrug $7.8 \mathrm{~mm}$ rechts und links und unterschied sich signifikant vom Kaliber der Milzarterie. Im Durchschnitt lag die Ursprungshöhe der Nierenarterien rechts höher als links. Statistisch signifikante Seitendifferenzen der Kaliber der Aa. iliacae communes, externae und internae bestanden nicht. In der höheren Altersklasse beobachteten wir ein Absinken der Aortenbifurkation und der Ursprünge der Nierenarterien, sowie eine deutliche Längenzunahme der Milzarterie. Die Länge der A. iliaca communis variierte beträchtlich. Diese Arterie war links etwas mehr geschlängelt als rechts. Beinahe immer trat eine derartige Schlängelung bei Hypertonikern auf.

\section{References}

Adachi, B.: Das Arteriensystem der Japaner. Bd. II, Kyoto 1928.

Arvidsson, H. : Acta Radiol. 1 (1963) 99-994 zit. n. I. Lize.

Baudisch, E. and J. Arndt: Atlas angiographischer Befunde bei Nierenerkrankungen und malignen Blasentumoren. G. Fischer, Jena 1969.

Bochenek, A. and M. Reicher: Anatomia czlowiecka. PZWL, t. 4, 1958.

Colquhoun, J.: Hypoplasia of the abdominal aorta following therapeutic irradiation in infancy. Radiology $86: 454-456,1966$ :

Danek, Z.: Obrazy radiologiczne pojedynczej tetnicy nerkowej w aortonephrography. 
Thesis, Krakau 1970.

Danek, Z.: Radiologic Anatomy of single renal artery on the basis of aortenephrography. Fol. Morph. 32: 433-443, 1973.

Danek, Z.: Tetnice dodatkowe nerek w aortonefrogramie. Pol. Przeg. Rad. Med. Nuk1. 38 : 31-38, 1974.

Danek, Z.: Przebieg i podzial tetnicy nerkowej w aortonefrogramie. Pol. Przeg. Med. Nuk1. 37 : 251-259, 1973.

Danek, Z.: Rozpoznawanie galezi grzbietowgi tetnicy nerkowej w aortonefrogramie. Pol. Przeg. Med. Nuk1. 37 : 399-403, 1973.

DeLuca, C. and DeSerio, N. : Studi di anatomia radiologica angiographica sul vivente. Radiol. med. 46 (1960) 120 ff., 435 ff.

DosSantos, R., A.C. Lamas et J. Caldas : Arteriographie des membres et de l'aorta abdominale. Masson, Paris 1931.

Edsmann, G.: Angionephrography and suprarenal angiography. Acta radiol. 1957, Suppl. 155.

Hafferl, A. : Lehrbuch der topographischen Anatomie, Springer, Heidelberg 1957.

Hou-Jensen, H. M. : Zit. nach Vogler and Herbst.

Heidsieck, E.: Zur Skeletotopie der großen Äste der Bauchaorta. Anat. Anz. 66 : 6-35, 1928.

Lize, I.: The descending aorta in different periods of mans life. Ann. Univ. M. Curie Skodl. Lublin 23 : 303-323, Section D, (1968).

Luzsa, G.: Röntgenanatomie des Gefäßsystems. J. Ambrosius Barth Verlag 1972.

Merklin, R. und N. A. Michels : Zit. nach Schobinger und Ruzicka.

Muratori, G. et L. Gotte: Il perimetro e 1 o spessore della aorta discendente e di alcune sue collaterali viscerali (arterie celiaca, mesenterica superiore, renale) in rapporto all' età, al sesso ed alla constituzione. Arch. it. Anat. Embriol. 55: 269-305, 1963.

Ödman, P: Percutaneous selective angiography of the coeliac artery. Acta radiol. Suppl. 159 (1958).

Olsson, O.: Selektive Nierenangiographie in : Ergebnisse der medizinischen Strahlenforschung, Bd. L. hrg. v. H. R. Schinz, R. Glauner, A. Rüttmann, Georg Thieme Stuttgart 1964.

Ney, C. and R. Friedenberg: Radiographic atlas of the genitourinary system. J.B. Lippincott, Philadelphia 1968.

Piasecki, Z., J. Pietrowski and F. Jugowski : Fol. morph. 13:183, 1962, ff. zit. n. Z. Danek.

Pietrowski, B. and W. Krylow: Leczenie chirurgiczne nadcisnienia nerkowonacyniowego, Warschau 1968.

Reich, W. J. and J. Nechtow: The iliac arteries. J. int. Coll. Surg. 41 : 53-60, 1964.

Rogalski, T.: Anatomia czlowiecka, t. 3 Czytelnik, Warschau 1952.

Schobinger, R. and F. Ruzicka: Vascular roentgenology. MacMillan, New York 1964.

Steinberg, C. R., M. Archer and I. Steinberg: Measurement of the abdominal aorta after intravenous aortography in health and arteriosclerotic peripheral vascular disease. Am. J. Roen. 95: 703-708, 1965.

Taber, P., M. T. Korobkin, C. A. Gooding, A. J. Palubinskas and E. B.D. Neuhause : Growth of the Abdominal Aorta and Renal Arteries in Childhood. Radiology 102 : 129-134, 1972.

Tassel, R.V.: Determination of the true size of the coronary artery in coronary arteriography. Am. J. Roen. 116: 62-65, 1972.

Töndury, G.: Angewandte und topographische Anatomie. G. Thieme Verlag, Stuttgart 1970.

Vogler, E. und R. Herbst: Angiographie der Nieren. Thieme Verlag, Stuttgart 1958. 
Wicke, L., H. P. Spängler, J. Dimopoulos, W. Firbas und F. Olbert : Zur Dignität deı Variationen der Nierenarterienabgänge im Angiogramm. Anat. Anz. 135: 140. $150,1974$.

\section{Explanations to the Figures}

\section{Plate I}

Fig. 1. Angiogram of a 54 year old female, hypertonic, occlusion of the left renal artery, white and black ink indicate the measurements. 
Plate I

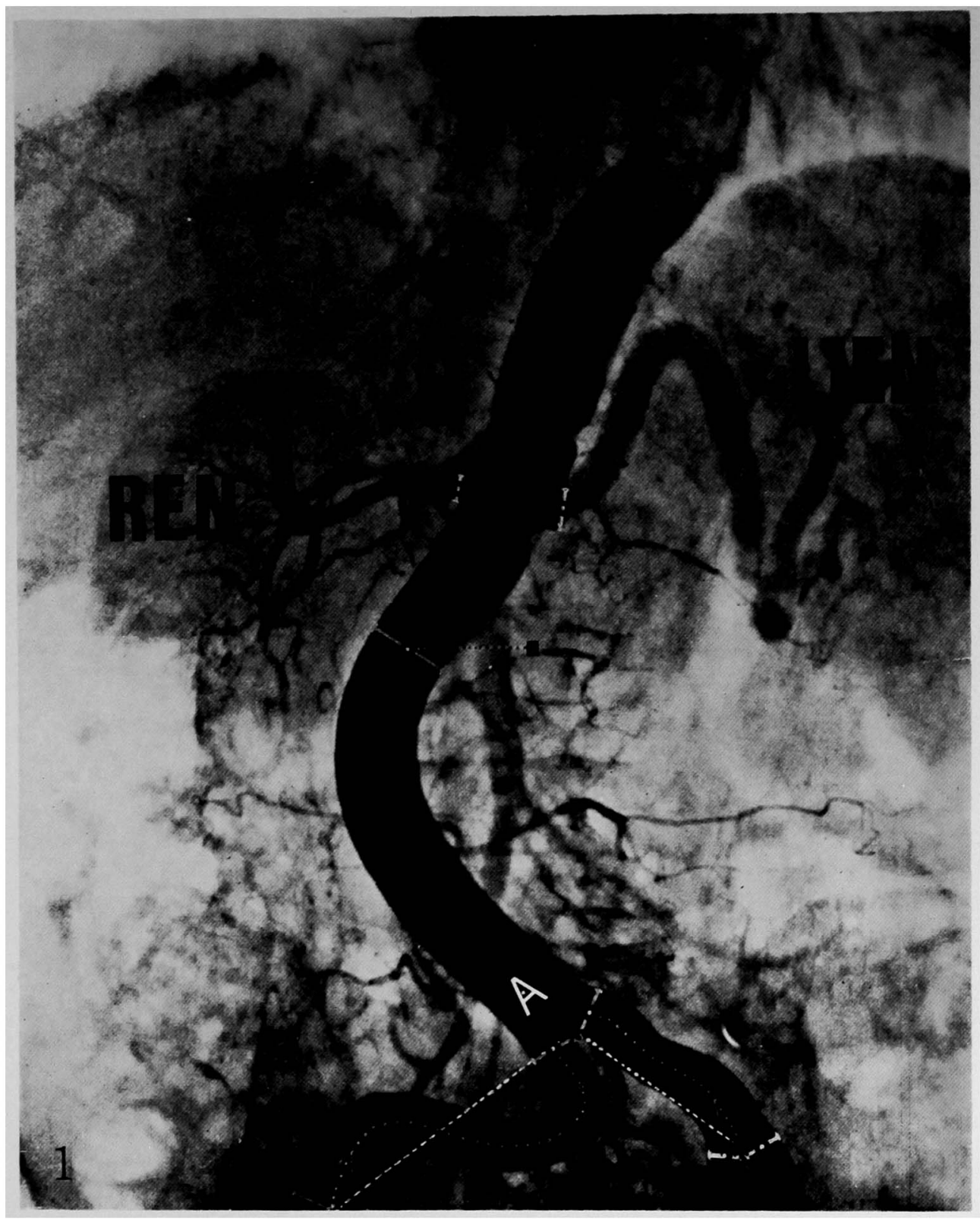

C. Leithner, et al. 


\section{Plate II}

Fig. 2. Scheme of the calibre (including standard deviation) of the abcominal aorta on various levels in $\mathrm{mm}$, on the right part the distance of the median line.

Fig. 3. Exact calibre in $\mathrm{mm}$ of the abdominal aorta in male and female on various levels. 
Plate Il

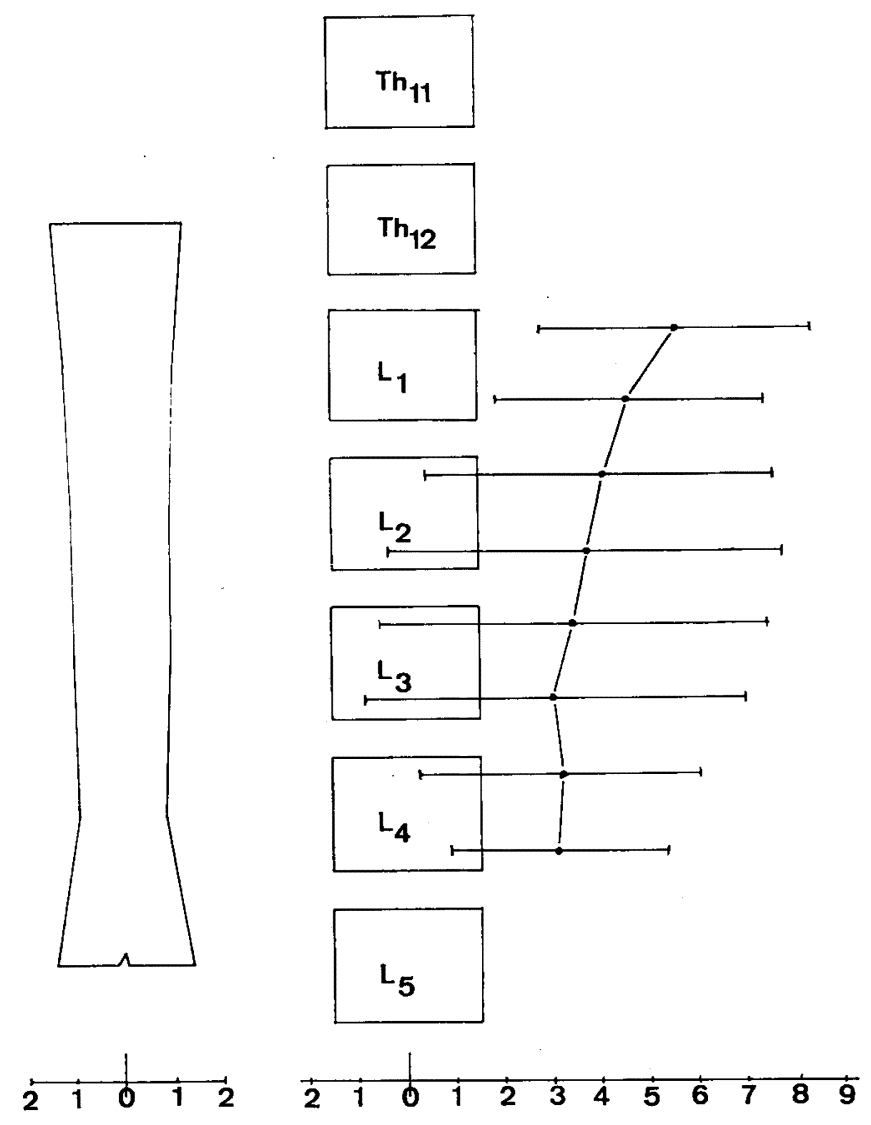

Fig. 2.

\begin{tabular}{|l|c|c|c|c|c|}
\hline level & $\mathrm{Th}_{12}$ & $\mathrm{~L}_{1}$ & $\mathrm{~L}_{2}$ & $\mathrm{~L}_{3}$ & $\mathrm{~L}_{4}$ \\
\hline male & 27,90 & 24,45 & 21,48 & 20,58 & 20,04 \\
\hline female & 23,96 & 22,11 & 19,07 & 19,21 & 18,01 \\
\hline
\end{tabular}

Fig. 3.

C. Leithner, et al. 


\section{Plate III}

Fig. 4. Angiogram of a 64 year old male, diabetic, note (arrows) the multiple oscil. lations of the aorta. 
Plate III

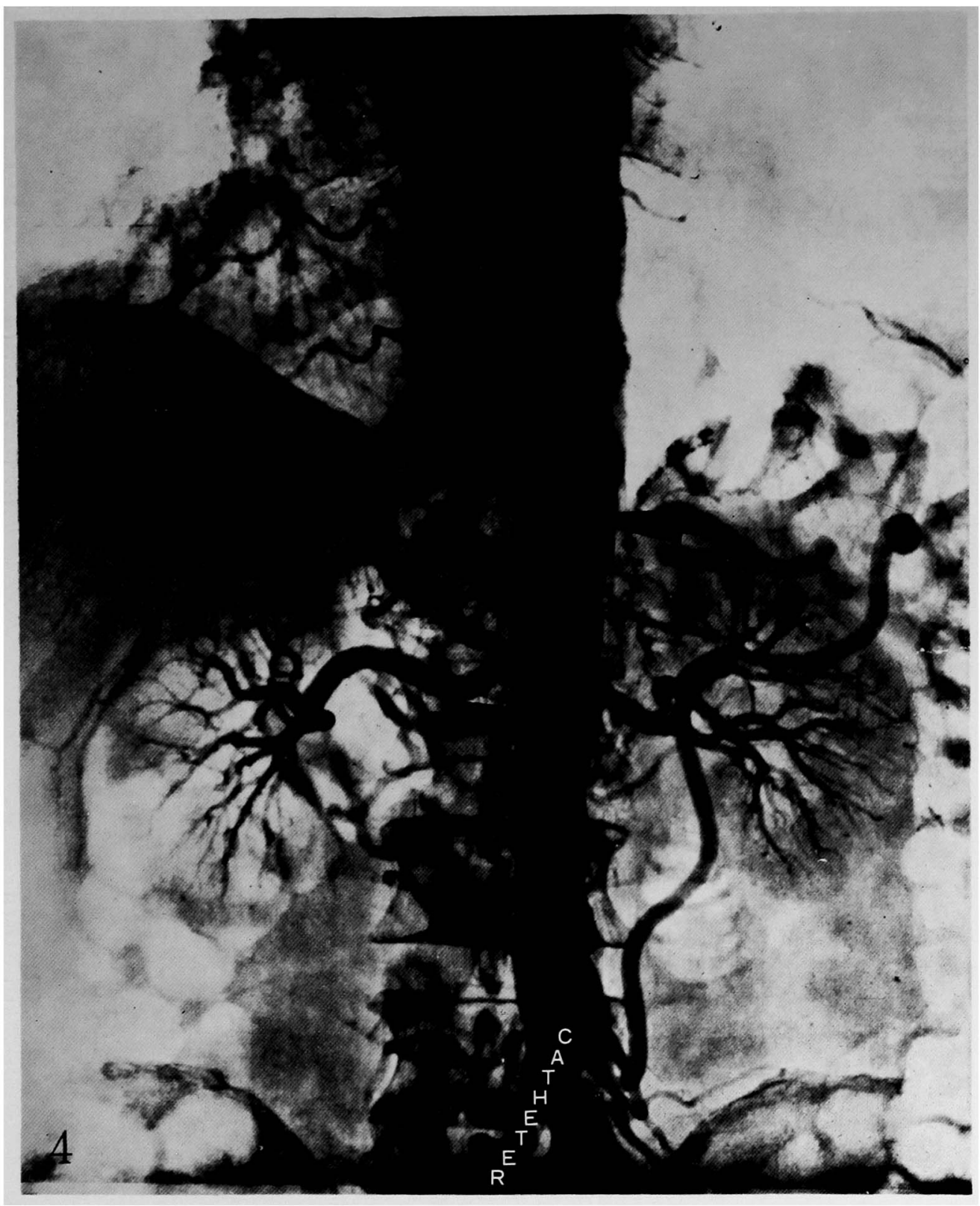

C. Leithner, et al. 


\section{Plate IV}

Fig. 5. Angiogram of a 37 year old diabetic male, note the repeated crossing of the aorta over the median line of the vertebral column. 
Plate IV

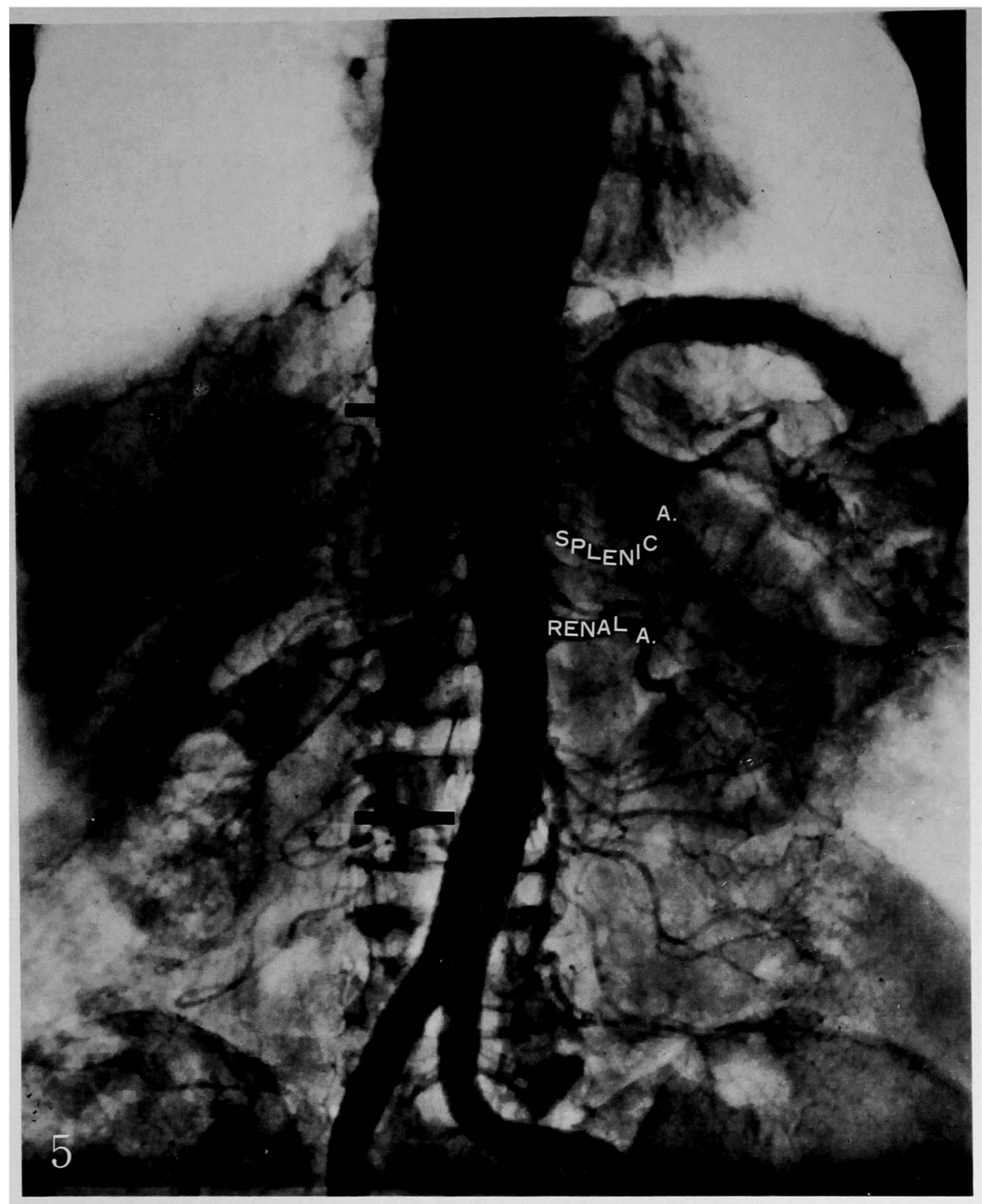




\section{Plate V}

Fig. 6. Summary of all statistically investigations, n...number, m....mean value, s standard deviation, FG 1 statistically significant, $O$ not significant, $90 \%$ level,

1 - 5 calibre of the aorta from $\mathrm{Th}_{12}-\mathrm{L}_{4}$

6 - 7 calibre of the right and left renal artery

8 calibre of the splenic artery

$9-16$ deviation of the aorta from the median line in the abdominal part (measurements on the upper and lower third of the vertebra)

17-18 calibre of the common iliac artery (right and left)

19-20 calibre of the external iliac artery (right a. left)

21-22 calibre of the internal iliac artery (right and left)

29-30 length of common iliac artery (right and left)-direct distance

31-32 length of the artery's course

33-34 distance of the bifurcation of iliac art. from median

$36,37,38$ angles of the bifurcations of the aorta, and right and left iliac arteries 


\begin{tabular}{|c|c|c|c|c|c|c|c|c|c|c|c|}
\hline & & $\mathrm{n}$ & $\mathbf{n}$ & $\mathrm{m}$ & $\mathrm{m}$ & $\mathbf{s}$ & $\mathbf{s}$ & & FG & & Plate V \\
\hline $\begin{array}{l}1 \\
1 \\
1 \\
1 \\
2 \\
2 \\
2 \\
3 \\
3\end{array}$ & $\begin{array}{l}2 \\
3 \\
4 \\
5 \\
3 \\
4 \\
5 \\
5 \\
4 \\
5\end{array}$ & $\begin{array}{l}56 \\
56 \\
56 \\
56 \\
61 \\
61 \\
61 \\
61 \\
61\end{array}$ & $\begin{array}{l}61 \\
61 \\
61 \\
55 \\
61 \\
61 \\
55 \\
61 \\
55\end{array}$ & $\begin{array}{l}26,14 \\
26,14 \\
26,14 \\
26,14 \\
23,29 \\
23,29 \\
23,29 \\
20,38 \\
20,38\end{array}$ & $\begin{array}{l}23,29 \\
20,38 \\
19,75 \\
18,95 \\
20,38 \\
19,75 \\
18,95 \\
19,75 \\
18,95\end{array}$ & $\begin{array}{l}3,51 \\
3,51 \\
3,51 \\
3,51 \\
3,38 \\
3,38 \\
3,38 \\
2,81 \\
2,81\end{array}$ & $\begin{array}{l}3,38 \\
2,81 \\
2,81 \\
2,56 \\
2,81 \\
2,81 \\
2,56 \\
2,81 \\
2,56\end{array}$ & $\begin{array}{r}4,4618 \\
9,7550 \\
10,8132 \\
12,3575 \\
5,1810 \\
6,2898 \\
7,8490 \\
1,2243 \\
2,8685\end{array}$ & $\begin{array}{l}1 \\
1 \\
1 \\
1 \\
1 \\
1 \\
1 \\
0\end{array}$ & $\begin{array}{l}115 \\
115 \\
115 \\
109 \\
120 \\
120 \\
114 \\
120 \\
114\end{array}$ & $\begin{array}{l}1,0753 \\
1,5567 \\
1,5601 \\
1,8728 \\
1,4477 \\
1,4508 \\
1,7417 \\
1,0021 \\
1,2031\end{array}$ \\
\hline $\begin{array}{l}6 \\
6 \\
7\end{array}$ & $\begin{array}{l}7 \\
8 \\
8\end{array}$ & $\begin{array}{l}58 \\
58 \\
60\end{array}$ & $\begin{array}{l}60 \\
53 \\
53\end{array}$ & $\begin{array}{l}7,81 \\
7,81 \\
7,80\end{array}$ & $\begin{array}{l}7,80 \\
7,19 \\
7,19\end{array}$ & $\begin{array}{l}1,46 \\
1,46 \\
1,40\end{array}$ & $\begin{array}{l}1,40 \\
1,24 \\
1,24\end{array}$ & $\begin{array}{l}0,0393 \\
2,4264 \\
2,4606\end{array}$ & $\begin{array}{l}0 \\
1 \\
1\end{array}$ & $\begin{array}{l}116 \\
109 \\
111\end{array}$ & $\begin{array}{l}1,0827 \\
1,3769 \\
1,2718\end{array}$ \\
\hline $\begin{array}{r}9 \\
9 \\
9 \\
9 \\
9 \\
9 \\
9 \\
10 \\
10 \\
10 \\
10 \\
10 \\
10 \\
11 \\
11 \\
11 \\
11 \\
11 \\
12 \\
12 \\
12 \\
12 \\
13\end{array}$ & $\begin{array}{l}10 \\
11 \\
12 \\
13 \\
14 \\
15 \\
16 \\
11 \\
12 \\
13 \\
14 \\
15 \\
16 \\
12 \\
13 \\
14 \\
15 \\
16 \\
13 \\
14 \\
15 \\
16 \\
14 \\
15 \\
16\end{array}$ & $\begin{array}{l}58 \\
58 \\
58 \\
58 \\
58 \\
58 \\
58 \\
58 \\
58 \\
58 \\
58 \\
58 \\
58 \\
59 \\
59 \\
59 \\
59 \\
59 \\
57 \\
57 \\
57 \\
57 \\
59 \\
59 \\
59\end{array}$ & $\begin{array}{l}58 \\
59 \\
57 \\
59 \\
60 \\
54 \\
30 \\
59 \\
57 \\
59 \\
60 \\
54 \\
30 \\
57 \\
59 \\
60 \\
54 \\
30 \\
59 \\
60 \\
54 \\
30 \\
60 \\
54 \\
30\end{array}$ & $\begin{array}{r}-10,55 \\
-10,55 \\
-10,55 \\
-10,55 \\
-10,55 \\
-10,55 \\
-10,55 \\
-9,38 \\
-9,38 \\
-9,38 \\
-9,38 \\
-9,38 \\
-9,38 \\
-8,09 \\
-8,09 \\
-8,09 \\
-8,09 \\
-8,09 \\
-7,75 \\
-7,75 \\
-7,75 \\
-7,75 \\
-7,02 \\
-7,02 \\
-7,02\end{array}$ & $\begin{array}{l}-9,38 \\
-8,09 \\
-7,75 \\
-7,02 \\
-6,20 \\
-6,28 \\
-6,13 \\
-8,09 \\
-7,75 \\
-7,02 \\
-6,20 \\
-6,28 \\
-6,13 \\
-7,75 \\
-7,02 \\
-6,20 \\
-6,28 \\
-6,13 \\
-7,02 \\
-6,20 \\
-6,28 \\
-6,13 \\
-6,20 \\
-6,28 \\
-6,13\end{array}$ & $\begin{array}{l}5,59 \\
5,59 \\
5,59 \\
5,59 \\
5,59 \\
5,59 \\
5,59 \\
5,74 \\
5,74 \\
5,74 \\
5,74 \\
5,74 \\
5,74 \\
7,27 \\
7,27 \\
7,27 \\
7,27 \\
7,27 \\
8,14 \\
8,14 \\
8,14 \\
8,14 \\
8,06 \\
8,06 \\
8,06\end{array}$ & $\begin{array}{l}5,74 \\
7,27 \\
8,14 \\
8,06 \\
7,81 \\
5,96 \\
5,50 \\
7,27 \\
8,14 \\
8,06 \\
7,81 \\
5,96 \\
5,50 \\
8,14 \\
8,06 \\
7,81 \\
5,96 \\
5,50 \\
8,06 \\
7,81 \\
5,96 \\
5,50 \\
7,81 \\
5,96 \\
5,50\end{array}$ & $\begin{array}{l}1,1140 \\
2,0596 \\
2,1445 \\
2,7593 \\
3,4893 \\
3,9053 \\
3,5516 \\
1,0699 \\
1,2350 \\
1,8278 \\
2,5255 \\
2 \cdot 7997 \\
2,5847 \\
0,2303 \\
0,7555 \\
1,3631 \\
1,4495 \\
1,4142 \\
0,4901 \\
1,0531 \\
1,0942 \\
1,1002 \\
0,5613 \\
0,5571 \\
0,6082\end{array}$ & $\begin{array}{l}0 \\
1 \\
1 \\
1 \\
1 \\
1 \\
1 \\
0 \\
0 \\
0 \\
1 \\
1 \\
1 \\
0 \\
0 \\
0 \\
0 \\
0 \\
0 \\
0 \\
0 \\
0 \\
0 \\
0 \\
0\end{array}$ & $\begin{array}{r}114 \\
115 \\
113 \\
115 \\
116 \\
110 \\
86 \\
115 \\
113 \\
115 \\
116 \\
110 \\
86 \\
114 \\
116 \\
117 \\
111 \\
87 \\
114 \\
115 \\
109 \\
85 \\
117 \\
111 \\
87\end{array}$ & $\begin{array}{l}1,0546 \\
1,6898 \\
2,1190 \\
2,0793 \\
1,9500 \\
1,1373 \\
1,0334 \\
1,6023 \\
2,0093 \\
1,9716 \\
1,8491 \\
1,0784 \\
1,0899 \\
1,2540 \\
1,2305 \\
1,1540 \\
1,4857 \\
1,7463 \\
1,0191 \\
1,0867 \\
1,8632 \\
2,1899 \\
1,0663 \\
1,8282 \\
2,1488\end{array}$ \\
\hline $\begin{array}{l}14 \\
14 \\
15\end{array}$ & $\begin{array}{l}15 \\
16 \\
16\end{array}$ & $\begin{array}{l}60 \\
60 \\
54\end{array}$ & $\begin{array}{l}54 \\
30 \\
30\end{array}$ & $\begin{array}{l}-6,20 \\
-6,20 \\
-6,28\end{array}$ & $\begin{array}{l}-6,28 \\
-6,13 \\
-6,13\end{array}$ & $\begin{array}{l}7,81 \\
7,81 \\
5,96\end{array}$ & $\begin{array}{l}5,96 \\
5,50 \\
5,50\end{array}$ & & $\begin{array}{l}0 \\
0\end{array}$ & $\begin{array}{r}112 \\
88 \\
82\end{array}$ & $\begin{array}{l}1,7146 \\
2,0152 \\
1,1753\end{array}$ \\
\hline $\begin{array}{l}17 \\
17 \\
17 \\
18 \\
18 \\
19\end{array}$ & $\begin{array}{l}18 \\
19 \\
20 \\
19 \\
20 \\
20\end{array}$ & $\begin{array}{l}58 \\
58 \\
58 \\
58 \\
58 \\
21\end{array}$ & $\begin{array}{l}58 \\
21 \\
18 \\
21 \\
18 \\
18\end{array}$ & $\begin{array}{r}11,90 \\
11,90 \\
11,90 \\
11,85 \\
11,95 \\
9,29\end{array}$ & $\begin{array}{r}11,95 \\
9,29 \\
9,33 \\
9,29 \\
9 ‘ 33 \\
9,33\end{array}$ & $\begin{array}{l}1,76 \\
1,76 \\
1,76 \\
1,94 \\
1,94 \\
1,68\end{array}$ & $\begin{array}{l}1,94 \\
1,68 \\
1,50 \\
1,70 \\
1,50 \\
1,50\end{array}$ & $\begin{array}{l}0,1502 \\
6,0268 \\
6,0782 \\
5,9686 \\
6,0122 \\
0,0937\end{array}$ & $\begin{array}{l}0 \\
1 \\
1 \\
1 \\
1 \\
0\end{array}$ & $\begin{array}{r}114 \\
77 \\
74 \\
77 \\
74 \\
37\end{array}$ & $\begin{array}{l}1,2112 \\
1,1058 \\
1,3922 \\
1,3393 \\
1,6862 \\
1,2590\end{array}$ \\
\hline 21 & 22 & 21 & 19 & 7,62 & 7,37 & 1,16 & 1,12 & 0,6958 & 0 & 38 & 1,0819 \\
\hline $\begin{array}{l}29 \\
29 \\
29 \\
30 \\
30 \\
31\end{array}$ & $\begin{array}{l}30 \\
31 \\
32 \\
31 \\
32 \\
32\end{array}$ & $\begin{array}{l}29 \\
29 \\
29 \\
26 \\
26 \\
29\end{array}$ & $\begin{array}{l}26 \\
29 \\
26 \\
29 \\
26 \\
26\end{array}$ & $\begin{array}{l}60,86 \\
60,86 \\
60,86 \\
65,00 \\
65,00 \\
94,17\end{array}$ & $\begin{array}{l}65,00 \\
64,17 \\
71,65 \\
64,17 \\
71,65 \\
71,65\end{array}$ & $\begin{array}{l}14,11 \\
14,11 \\
14,11 \\
14,54 \\
14,54 \\
15,52\end{array}$ & $\begin{array}{l}14,54 \\
15,52 \\
16,80 \\
15,52 \\
16,80 \\
16,80\end{array}$ & $\begin{array}{l}1,0683 \\
0,8498 \\
2,5636 \\
0,2041 \\
1,5270 \\
1,7093\end{array}$ & $\begin{array}{l}0 \\
0 \\
1 \\
0 \\
0 \\
0\end{array}$ & $\begin{array}{l}53 \\
56 \\
53 \\
53 \\
50 \\
53\end{array}$ & $\begin{array}{l}1,0619 \\
1,2092 \\
1,4165 \\
1,1387 \\
1,3340 \\
1,1714\end{array}$ \\
\hline 3 & 34 & 29 & 27 & 31,41 & 41,22 & 9,38 & 9,62 & 3,8587 & 1 & 54 & 1,0505 \\
\hline $\begin{array}{l}36 \\
36 \\
97\end{array}$ & $\begin{array}{l}37 \\
38 \\
38\end{array}$ & $\begin{array}{l}59 \\
59 \\
14\end{array}$ & $\begin{array}{l}14 \\
18 \\
18\end{array}$ & $\begin{array}{l}36,83 \\
36,83 \\
41,00\end{array}$ & $\begin{array}{l}41,00 \\
29,06 \\
29,06\end{array}$ & $\begin{array}{r}9,99 \\
9,99 \\
20,35\end{array}$ & $\begin{array}{l}20,35 \\
15,76 \\
15,76\end{array}$ & $\begin{array}{l}0,7454 \\
1,9757 \\
1,8134\end{array}$ & $\begin{array}{l}0 \\
0 \\
0\end{array}$ & $\begin{array}{l}71 \\
75 \\
30\end{array}$ & $\begin{array}{l}4,1500 \\
2,4871 \\
1,6686\end{array}$ \\
\hline
\end{tabular}

C. Leithner, et al. 


\section{Plate VI}

Fig. 7. Scheme of a mean value of the bifurcations of the aorta and iliac arteries with standard deviations of the angles and of the length of the arteries.

Fig. 8a. Level of the aortic bifurcation to the vertebral volumn, and the number of cases, for symboles look Fig. 8b. 
Plate VI

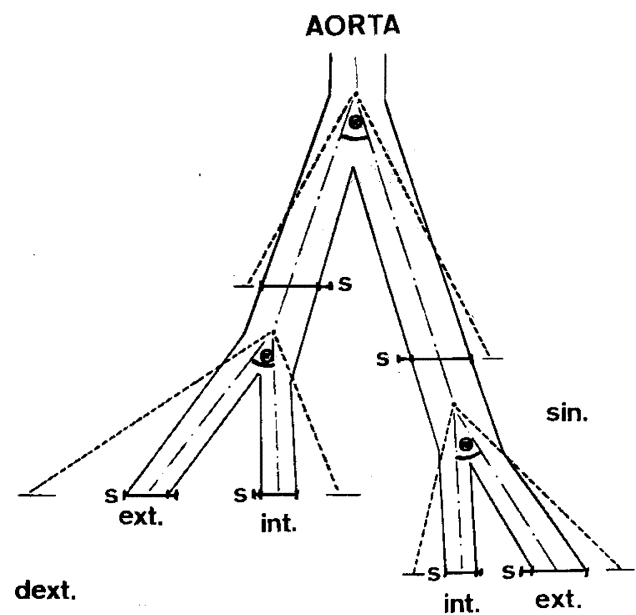

Fig. 7.

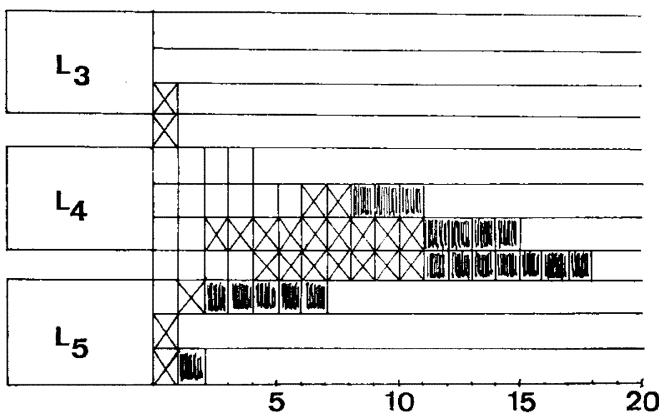

aortic bifurcation

Fig. 8-a.

C. Leithner, et al. 


\section{Plate VII}

Fig. 8b. Level of the aortic bifurcation, on the left males, on the right females.

Fig. 9. Calibre and number of the renal and splenic arteries, note that there is nc statistically significant difference. 
Plate VI]

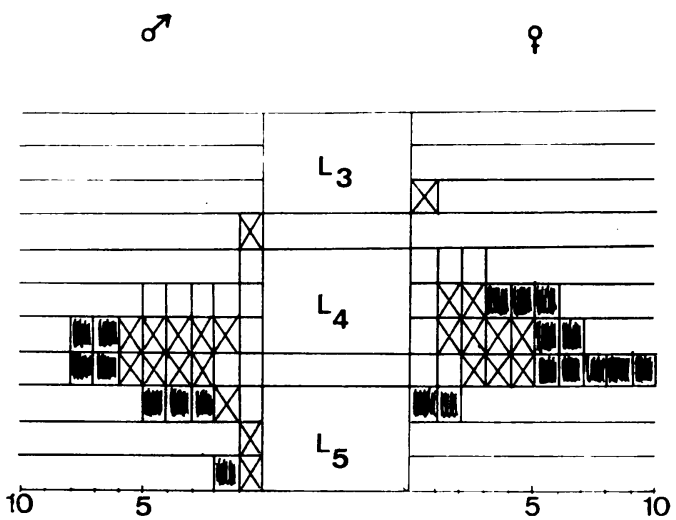

symbol for age-classes

$<40$

$\square$

41.59 冈

$>60$

Fig. 8-b.

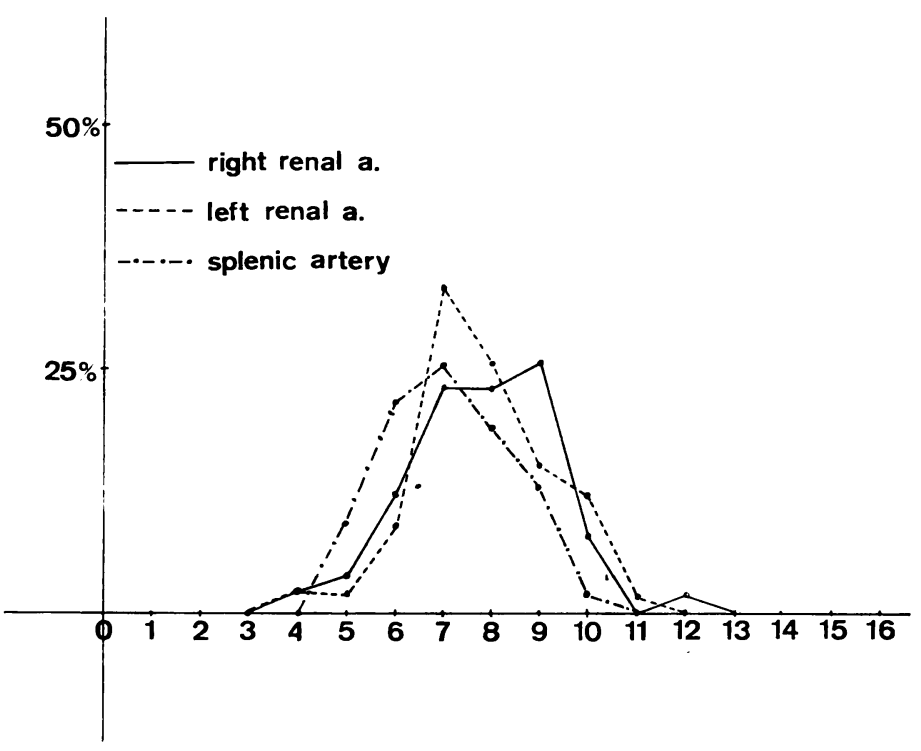

Fig. 9.

C. Leithner, et al. 


\section{Plate VIII}

Fig. 10. Level of the origin of the renal artery of both sexes to the vertebral column, note the symboles for age classes from Fig. $8 \mathrm{~b}$.

Fig. 11. Level of the origin of the renal arteries from males. 
Plate VIII

ri

le

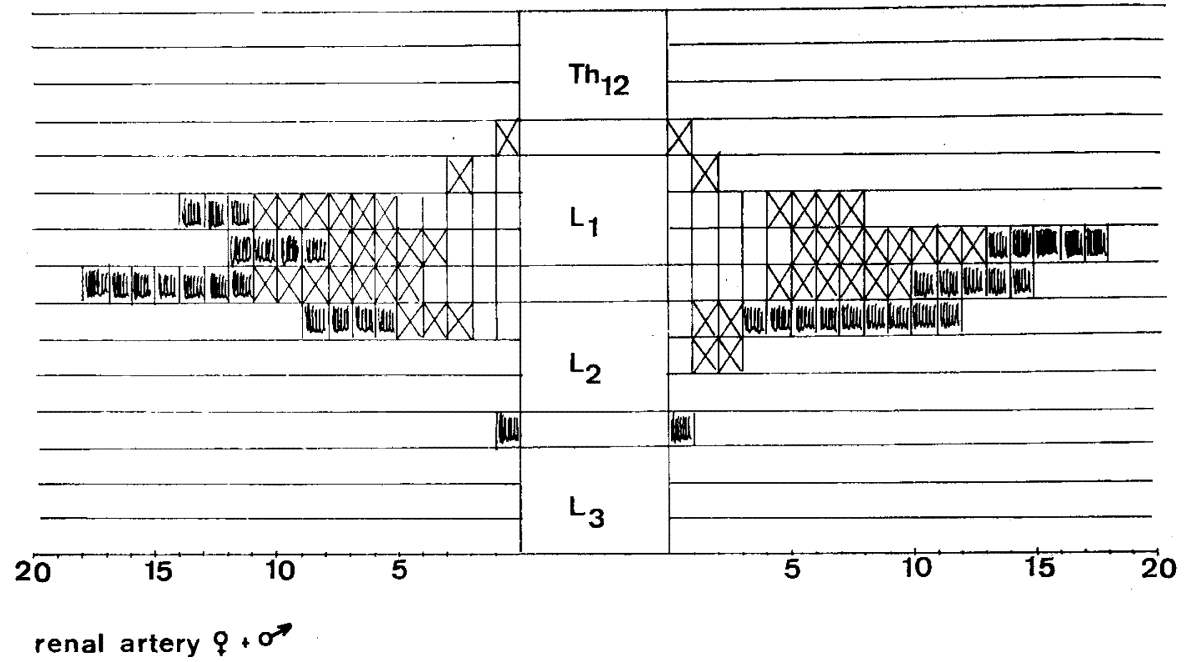

Fig. 10.

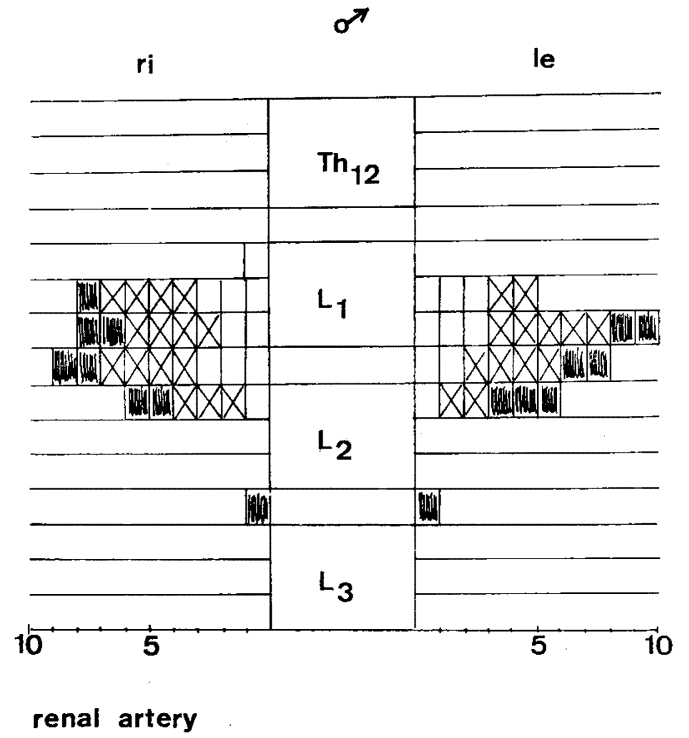

Fig. 11.

C. Leithner, et al. 


\section{Plate IX}

Fig. 12. Level of the origin of the renal arteries from females.

Fig. 13. Level of the origin of the splenic artery, on the left males, on the right, females, for age classes compare Fig. 8b. 
Plate IX

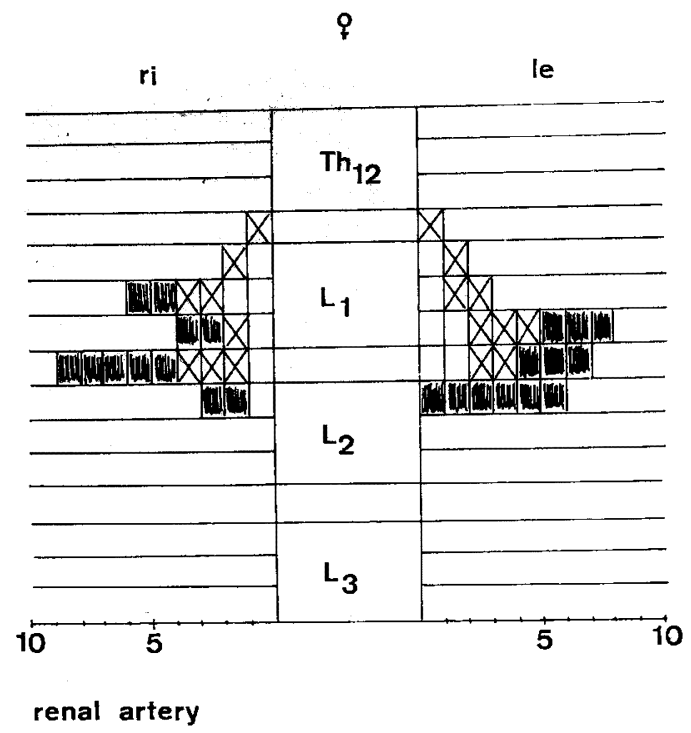

Fig. 12.

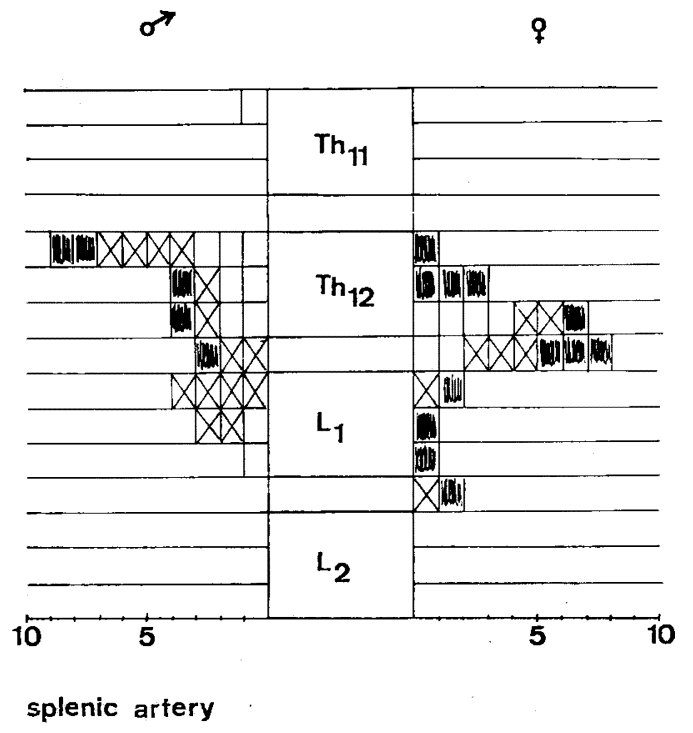




\section{Plate $\mathrm{X}$}

Fig. 14 Angiogram of a 50 year old diabetic and hypertonic male, atherosclerotic oscillations of the lower part of the abdominal aorta, high tortuosity of the splenic artery (arrow). 
Plate X

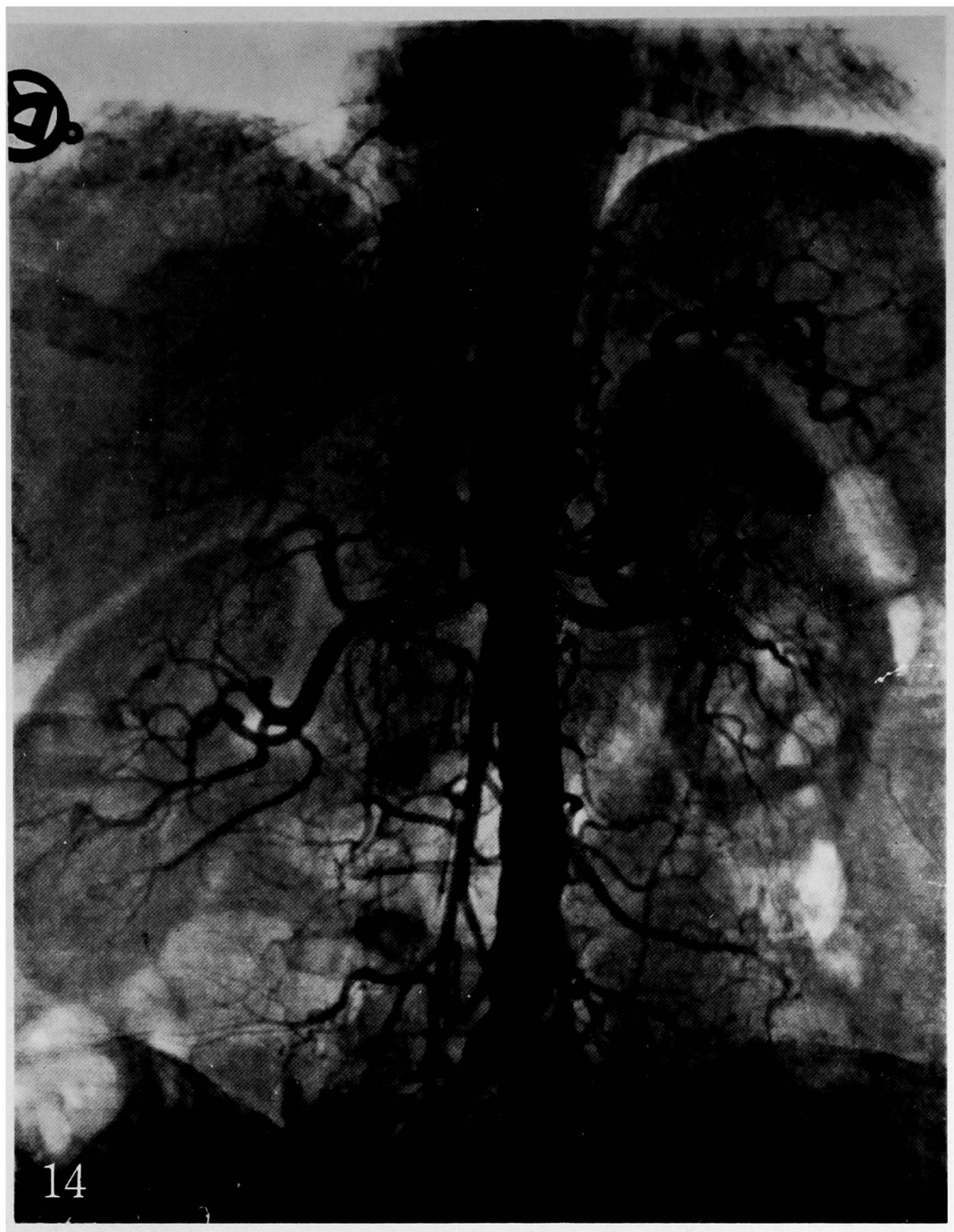

C. Leithner, et al. 


\section{Plate XI}

Fig. 15. Caliber in $\mathrm{mm}$ and number in percent of the both common iliac arteries, note, that there is no statistically significant difference. 
Plate XI

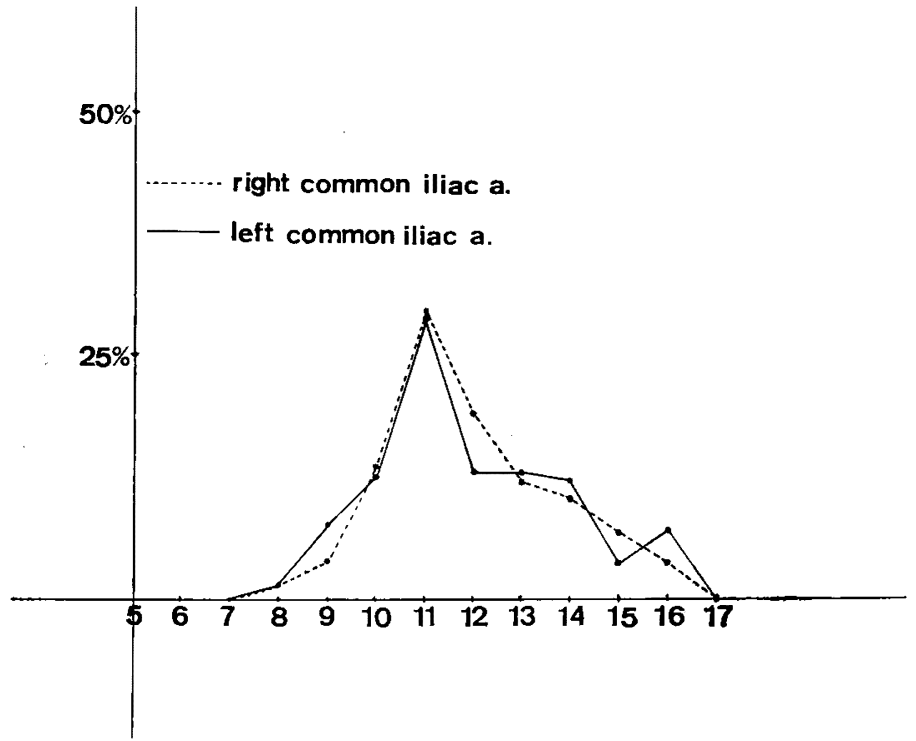

Fig. 15.

C. Leithner, et al. 


\section{Plate XII}

Fig. 16. Angiogram of a 4 year old, hypertonic male, note the tortuosity of the abdominal aorta as well as from their great branches 
Plate XII

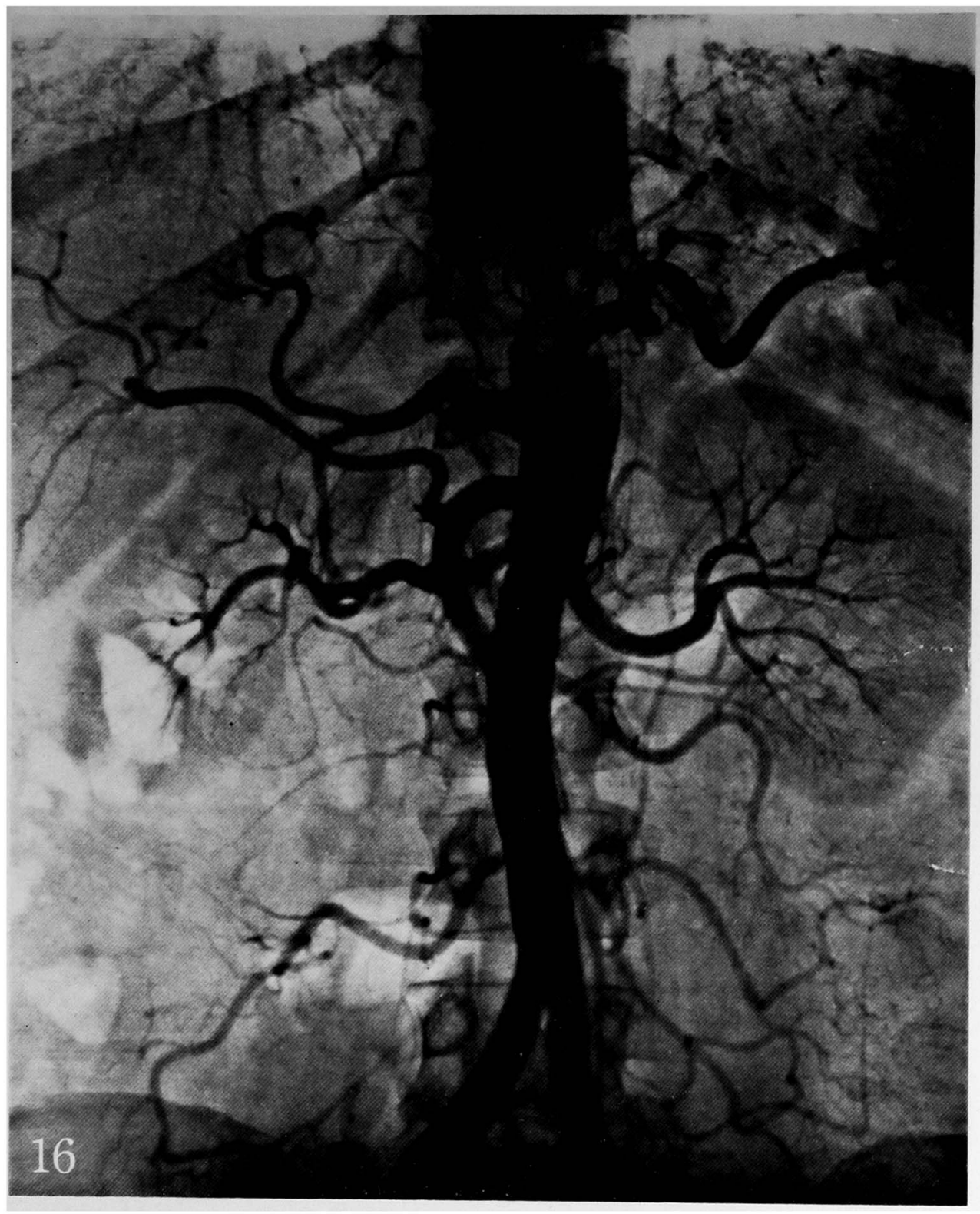

C. Leithner, et al. 